\title{
Elimination of lime causing clogging in emitters by chemical methods in drip irrigation
}

\author{
Ömer Faruk KARACA ${ }^{1 *}$ and Kenan UÇAN ${ }^{2}$ \\ ${ }^{1}$ Department of Biosystems Engineering, Faculty of Engineering and Architecture, University of Bozok, 66200 Yozgat, \\ Turkey. \\ ${ }^{2}$ Department of Biosystems Engineering, Faculty of Agriculture, University of Kahramanmaras Sutcu Imam, \\ 46100 Kahramanmaras, Turkey.
}

Accepted 25 February, 2013

\begin{abstract}
Emitter clogging is one of the most serious problems facing users of drip irrigation systems using poor irrigation water and groundwater. It can affect negatively irrigation system performance and crop yield. The objectives of this study were to to determine the appropriate $\mathrm{HCl}$ amount $(2.5,5,10,500$ and 1000 ppm) and whether these acid rates could open the clogged emitters $(25,50$ and $100 \%)$ with additional $\mathrm{CaCO}_{3}$ or not. Firstly, laterals were filled with water without using any pomp, then water-filled laterals were inversed and placed on the ground under the sun. But, it was realized that there were no clogging using that method. Therefore, based on calculated Langelier saturation index, lime-water was used. After the desired clogging, water with acid mixture were injected into the system and water samples were collected one in five meters for each lateral. Chemical analysis was carried out for each sample. The results of the study showed that $2.5,5$ and $10 \mathrm{ppm}$ acid rates could not sufficiently open the clogged emitters. The highest percentages of opening were obtained in $1000 \mathrm{ppm}$ with 40.91 for $25 \%$ clogged laterals.
\end{abstract}

Key words: Drip irrigation, $\mathrm{HCl}$ application, Langelier saturation index, water quality.

\section{INTRODUCTION}

Drip irrigation is the most efficient method for irrigation, especially arid and semi-arid regions. However, the clogging of emitters is one of the most serious problems facing users of drip irrigation systems using poor irrigation water and groundwater. This undesirable case can adversely affect the system performance and crop yield (Dehghanisanij et al., 2007; Gilbert et al., 1979). Bucks and Nakayama (1982) proposed an irrigation water quality classification for potential clogging hazard. They categorized the clogging into three essential categories. These are physical (by suspended solids), chemical (by precipitation of lime and scales) and biological (by bacterial and algal growth). Clogging mostly is caused by one or more of these factors. The most common physical causes of clogging of drip emitters are sand particles, which are usually found in surface and unstrained underground water. Biological clogging results from the growth of bacterial and algal growth within drip tapes and emitters. They combine with clay particles to block the emitters. Chemical precipitate is usually caused by exceeding precipitation of one or more of such minerals as calcium, magnesium, iron and manganese. 
The most dangerous of these are sulphur and iron precipitations. Calcium carbonate or lime precipitation problem essentially depends on the $\mathrm{pH}$ of the water. Keller and Bliesner (1990) found that the water containing bicarbonate concentration greater than $2 \mathrm{me} / \mathrm{l}$ and a $\mathrm{pH}$ value greater than 7.5 likely could create calcium precipitation. Calcium carbonate precipitation can be observed in the form of a whitish deposit in emitters and micro-sprinklers. The relationship between bicarbonate and the $\mathrm{pH}$ of water showed that falling $\mathrm{pH}$ could prevent or reduce clogging of the carbonate in the system.

In order to predict what might cause chemical plugging of microirrigation system emitters, the process of mineral deposition must be understood. Carbon-dioxide gas $\left(\mathrm{CO}_{2}\right)$ is of particular importance in the dissolution and deposition of minerals. Water adsorbs some $\mathrm{CO}_{2}$ from the air, but larger quantities are adsorbed from decaying organic matter as water passes through the soil. Under pressure, as is groundwater, the concentration of $\mathrm{CO}_{2}$ increases to form carbonic acid. This weak acid can readily dissolve mineral compounds such as calcium carbonate to form calcium bicarbonate which is soluble in water. This process allows calcium carbonate to be dissolved, transported, and under certain conditions, again redeposited as calcium carbonate (Pitts et al., 1990).

There are some methods used to prevent clogging or partially clogging of emitters. The most usable and easy methods of these is acid injection. As a rule of thumb, the $\mathrm{pH}$ of water in the system should be lowered to near 2.0 to achieve maximum effectiveness of the acidification (Rible and Meyers, 1986). Acidification treatment lowers the $\mathrm{pH}$ so that the compounds and precipitates that are strongly bonded and insoluble under normal conditions can dissociate. The acid supplies an excessive amount of highly reactive positive hydrogen ions to the irrigation water. These hydrogen ions react with the dissociated anions to form soluble compounds that can be flushed from the system (Boman and Ontermaa, 1994).

Acids have been used to lower $\mathrm{pH}$ and reduce the potential for chemical precipitation (Pitts et al., 1990). Sulfiric $\left(\mathrm{H}_{2} \mathrm{SO}_{4}\right)$, hydrochloric $(\mathrm{HCl})$, phosphoric $\left(\mathrm{H}_{3} \mathrm{PO}_{4}\right)$ and nitric $\left(\mathrm{HNO}_{3}\right)$ acid are used for this purpose. Coelho (2001) found that for all types of emitters, excepting one, it was seen that applied chlorine $(\mathrm{Cl})$ rate enhanced the flow rate. To ensure continuity of free $\mathrm{Cl}$ in closed pipe system, the initial concentration of 5-6 ppm was required (Granberry et al., 2009). Stephen (1985) Suggested injecting $\mathrm{Cl}$ level with 30-60 min day ${ }^{-1}$ and $10-20 \mathrm{ppm}$ concentration in order to remove the consisted deposits.

The objectives of this study were to determine the appropriate $\mathrm{HCl}$ amount $(2.5,5,10,500$ and $1000 \mathrm{ppm})$ and whether these amount could open the clogged emitters (25, 50 and $100 \%)$ with additional $\mathrm{CaCO}_{3}$ or not. In addition, the study also aims to determine when the natural clogging of emitters with sun effect and to determine the effect of clogging along lateral line.

\section{MATERIALS AND METHODS}

\section{Experimental location}

Due to its location, Kahramanmaraş has a mild Mediterranean climate with a twist of South-Eastern Anatolian climate. The average temperature is $16.5{ }^{\circ} \mathrm{C}$ all year round in the city centre. Summers are hot and dry with an average of $35^{\circ} \mathrm{C}\left(95^{\circ} \mathrm{F}\right)$ but can go higher than $+40^{\circ} \mathrm{C}\left(104^{\circ} \mathrm{F}\right)$. Winters are cold and damp with temperatures ranging from $0-5^{\circ} \mathrm{C}\left(32-41^{\circ} \mathrm{F}\right)$. The average annual rainfall is $709.8 \mathrm{~mm}$. Rain falls mostly during the winter. Kahramanmaraş has $14.237 \mathrm{~km}^{2}$ area and is the $13^{\text {th }}$ big province of Turkey.

\section{Experimental layout}

The study was conducted in a research field in Agricultural Faculty of Avsar Campus of Kahramanmaras Sutcu Imam University in 2009. Research area is located at $37^{\circ} 36^{\prime} \mathrm{N}$ latitude, $36^{\circ} 55^{\prime} \mathrm{E}$ longitude and altitude is $600 \mathrm{~m}$. For the experiment, a flat topography was selected (Figure 1).

In this study, the percentages of clogging were selected as 25 , 50 and $100 \%$ and the concentrations were selected as $2.5,5,10$, 500 and $1000 \mathrm{ppm}$. The main reason for high concentration selections as 500 and 1000 ppm were to determine which concentration opens the emitters completely. The study was designed in a randomized complete plot design with three replications.

The schematic view of system is given in Figure 2. The system had 4 plastic tank with $1000 \mathrm{~L}$ volume, main pipe with 40 and 63 $\mathrm{mm}$ diameters. Laterals had $20 \mathrm{~cm}$ emitter space, $3 \mathrm{l} / \mathrm{h}$ emitter flow rate and $16 \mathrm{~mm}$ diameter in-line emitters. Each lateral had 50 emitters and each of them was $10 \mathrm{~m}$ long. To prevent the accumulation of chemicals along the flow path in the emitter, operating pressure must not be less than 1 atm (Güngör et al., 2004). Therefore, the system was operated under $1.5 \mathrm{~atm}$ constant pressure.

\section{Properties of water source}

Irrigation water used in the study was provided from tap water based in Avsar Campus of the Kahramanmaras Sutcu Imam University. The irrigation water was analysed by methods as specified by Tüzüner (1990).

\section{Determination of Langelier saturation index value}

Langelier saturation index (LSI) was used to provide desired clogging levels in emitters. According to this index, lime water constituted by adding lime in specific rates were injected into the emitters. LSI is an index that determines the carbonate deposit. This helps determine the scaling potential of the water. A positive LSI indicates that $\mathrm{CaCO}_{3}$ can precipitate. A negative LSI indicates that the water is corrosive to steel. Metcalf and Eddy (2003) used the index of LSI or Ryzner for estimation of calcium carbonate concentration in water so as to determine the potential of $\mathrm{CaCO}_{3}$ precipitation formation of waste waters. LSI classification and factors used in calculation is shown in Table 1. According to data analysis, LSI values were determined with the following equation by the help of actual factors:

$$
\mathrm{LSI}=\mathrm{pH}+\mathrm{AF}+\mathrm{CF}+\mathrm{TF}-12.1
$$

Where, $\mathrm{pH}$, Irrigation water acidic-alkaline value (measured by $\mathrm{pH}$ meter); $\mathrm{AF}$, alkalinity factor (according to $\mathrm{Na}$ ion concentration); $\mathrm{CF}$, calcium hardness factor (according to $\mathrm{Ca}$ ion concentration); TF, 


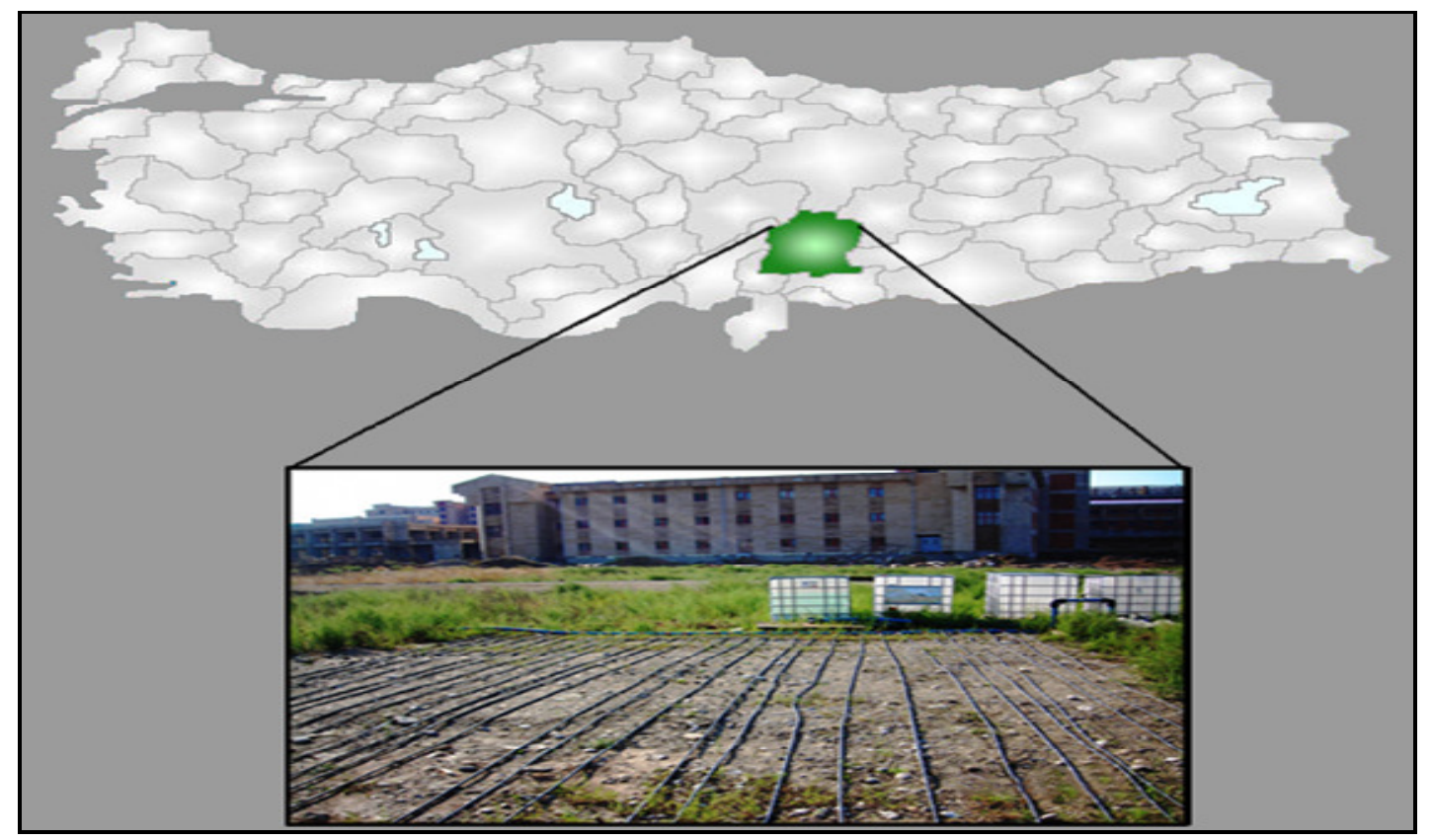

Figure 1. Experimental Layout.

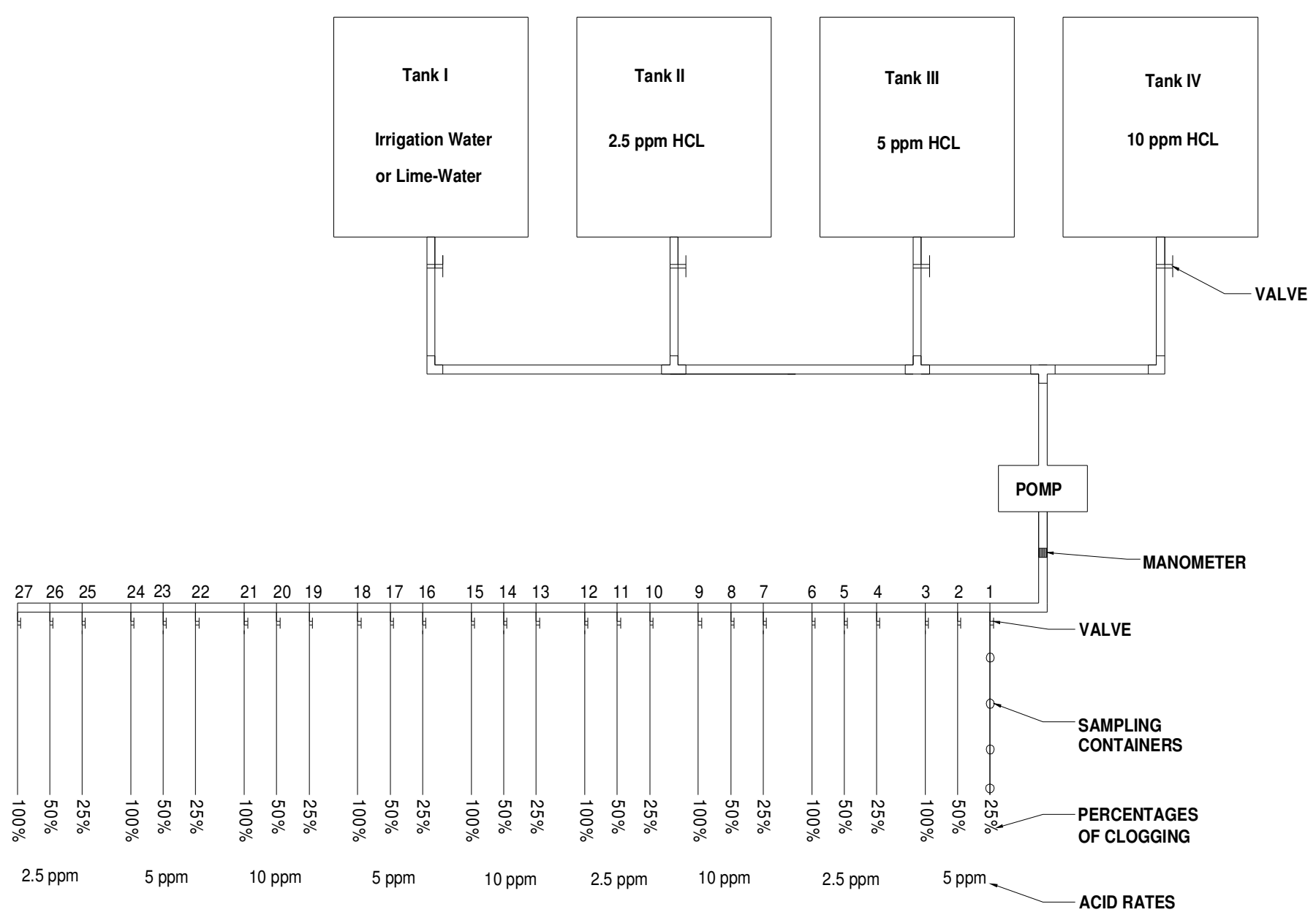

Figure 2. The schematic view of system. 
Table 1. Langelier saturation index factors.

\begin{tabular}{cccccc}
\hline $\begin{array}{c}\text { Temperature } \\
\left({ }^{\circ} \mathbf{C}\right)\end{array}$ & Factor & $\begin{array}{c}\text { Alkalinity } \\
(\mathbf{p p m})\end{array}$ & Factor & $\begin{array}{c}\text { Calcium hardness } \\
(\mathbf{p p m})\end{array}$ & Factor \\
\hline 0 & 0.0 & 5 & 0.7 & 5 & 0.3 \\
3 & 0.1 & 25 & 1.4 & 25 & 1.0 \\
8 & 0.2 & 50 & 1.7 & 50 & 1.3 \\
12 & 0.3 & 75 & 1.9 & 75 & 1.5 \\
16 & 0.4 & 100 & 2.0 & 100 & 1.6 \\
19 & 0.5 & 150 & 2.2 & 150 & 1.8 \\
24 & 0.6 & 200 & 2.3 & 200 & 1.9 \\
29 & 0.7 & 300 & 2.5 & 300 & 2.1 \\
34 & 0.8 & 400 & 2.6 & 400 & 2.2 \\
41 & 0.9 & 800 & 2.9 & 800 & 2.5 \\
\hline
\end{tabular}

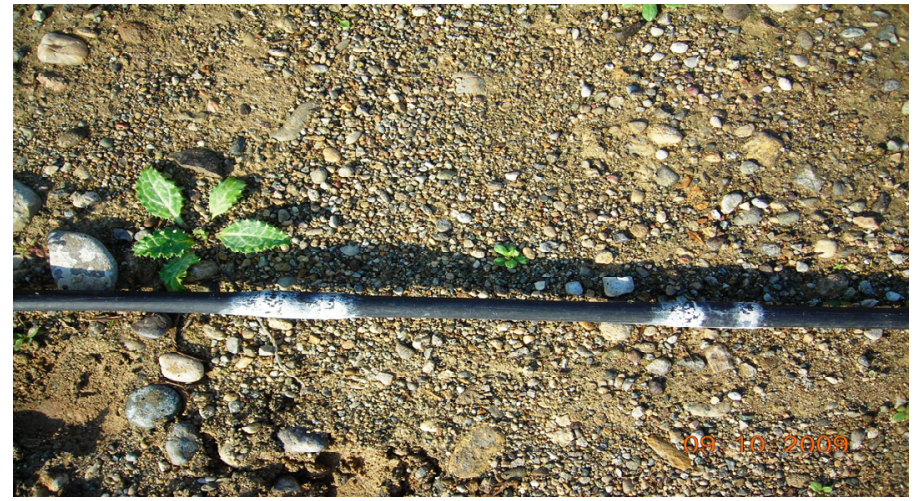

Figure 3. Scale and deposit on laterals during lime-water application.

temperature factor (according to measured irrigation water temperatures)

According to obtained $\mathrm{LSI}$ values, if, $\mathrm{LSI}>+2.0$, Highly scale occurs; $+0.5<\mathrm{LSI}<+2.0$, scale occurs; $\mathrm{LSI}=0$, water is neutral; $2.0<\mathrm{LSI}<-0.5$, water is slightly corrosive; LSI $<-2.0$, water is highly corrosive.

\section{Distribution of water into the system}

Firstly, laterals were filled with water without using any pomp, water-filled laterals were inversed and placed on the ground under the sun. Until the water in the laterals had evaporated (approximately $2 \mathrm{~h}$ ), water samples were not taken. After the water in the laterals had evaporated, water samples were taken by measuring the flow rate. So, percentages of clogging were determined. These procedures were repeated throughout the day and totally, it was continued for a month. Finally, it was realized that there were no clogging using these procedures.

Hence, until the desired percentages of clogging were reached (25, 50 and $100 \%$ ), lime-water mixtures was determined by LSI values. At the end of each lime-water application, the clogged emitters were determined by injecting clean water and measuring the flow rates. When the desired percentages of clogging were reached, the mini-valve of this lateral was closed (Figure 3 ). For the other laterals, it was continued in the same way until it reached the desired rates. In the determination of percentages of clogged

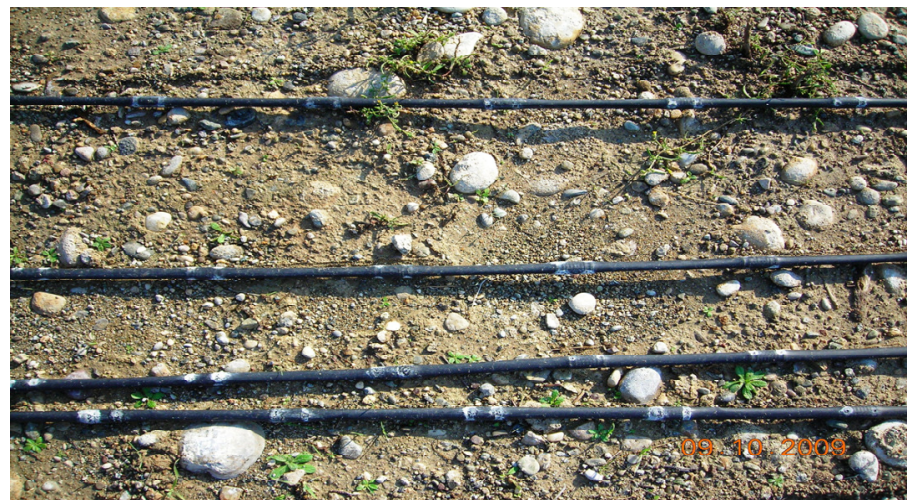

emitter, similar to that done by Smajstrla et al. (1983), the method of control of clogging emitters in total emitters were used. For this reason, the systems were installed in order that each lateral has 50 emitters.

\section{Properties of acid and usage}

Muriatic $(\mathrm{HCl})$ acid is probably the most effective in dissolving majority of the scales. Muriatic acid generally does not produce harmful precipitation reactions and also it is often chemically the most effective in dissolving the precipitates. Therefore, $\mathrm{HCl}$ acid was used to open the clogged emitters. By injecting $\mathrm{HCl}$ acid to the system, it was aimed to removing the clogging by dissolving the lime and removing it from the emitter.

In this study, acid evenly was mixed in the tank and it was injected throughout the system and allowed to stay for $30 \mathrm{~min}$. intermittent chlorination method was used for injection as described by Netafim (2000). When the water was seen at the end of laterals, valve of the mixture of acid-water were turned off and waited for occuring reaction between acid and lime. Application was maintained until the mixture of acid-water in tank was run out. Meanwhile, as the acid application proceeds, water samples were taken from the tank and the laterals for chemical analysis. As described in Stephen (1985) and Evans (2001), water samples were taken from emitters in every two meters with 30 min intervals. The main mixture was obtained by mixing all subsamples for one 
Table 2. Irrigation water analysis results and water quality criteria.

\begin{tabular}{ccclc}
\hline Ion & me/L & ppm & Other water quality criteria & \\
\hline $\mathrm{Ca}^{+2}$ & 1.34 & 26.75 & $\mathrm{EC}(\mathrm{dS} / \mathrm{m})$ & 0.42 \\
$\mathrm{Mg}^{+2}$ & 2.53 & 30.39 & $\mathrm{pH}$ & 7.60 \\
$\mathrm{Na}^{+}$ & 0.21 & 4.80 & $\mathrm{SAR}(\mathrm{me} / \mathrm{l})$ & 0.15 \\
$\mathrm{~K}^{+}$ & 0.03 & 1.20 & $\mathrm{RSC}(\mathrm{me} / \mathrm{l})$ & -3.72 \\
$\mathrm{CO}_{3}^{-2}$ & 0.00 & 0.00 & $\% \mathrm{Na}$ & 5.08 \\
$\mathrm{HCO}_{3}^{-}$ & 0.15 & 9.15 & $\mathrm{TDS}(\mathrm{ppm})$ & 256.70 \\
$\mathrm{Cl}^{-}$ & 0.43 & 15.27 & Hardness $\left(\mathrm{CaCO}_{3}\right)(\mathrm{ppm})$ & 57.14 \\
$\mathrm{SO}_{4}^{-2}$ & 3.53 & 169.42 & & \\
\hline
\end{tabular}

Table 3. Important Quality Parameters of Irrigation Water (Çolakoğlu, 2010).

\begin{tabular}{lcccc}
\hline Quality class of water & EC (dS/m) & TDS (ppm) & Na (\%) & Cl (me/l) \\
\hline Excellent & $<0.25$ & $<175$ & $<20$ & $<0.5$ \\
Good & $0.25-0.75$ & $175-525$ & $20-40$ & $0.5-1.25$ \\
Middle & $0.75-2.0$ & $525-1400$ & $40-60$ & $1.25-2.5$ \\
Poor & $2.0-3.0$ & $1400-2100$ & $60-80$ & $2.5-5.0$ \\
Very Poor & $>3.0$ & $>2100$ & $>80$ & $>5.0$ \\
\hline
\end{tabular}

EC, Electrical conductivity; TDS, total dissolved solids, SAR, sodium adsorption ratio.

lateral. As described in Tüzüner (1990), electrical conductivity (EC) - $\mathrm{pH}$ measurements and anion $\left(\mathrm{CO}_{3}^{-}, \mathrm{HCO}_{3}^{-}, \mathrm{Cl}^{-}\right.$and $\left.\mathrm{SO}_{4}^{-}\right)$and cation $\left(\mathrm{Ca}^{++}, \mathrm{Mg}^{++}, \mathrm{Na}^{+}\right.$and $\left.\mathrm{K}^{+}\right)$analyses were performed. Then the changes on total dissolved solids (TDS), sodium adsorption ratio (SAR), $\mathrm{Na} \%$ and $\mathrm{Cl}$ were determined. Consequently, the relationship between acid rates injected into the system and percentages of openings were compared. Data was analyzed by using Statistical Package for Social Sciences (SPSS) program for the randomized complete plot design with three replications. Chemical analyses data were compared with lower and upper limit values of current existing literature.

\section{RESULTS AND DISCUSSION}

\section{Properties of water source}

The irrigation water was analysed by methods as described by Tüzüner (1990) and the results obtained are given in Table 2. According to chemical analysis results, the hardness leading to the formation of $\mathrm{CaCO}_{3}$ wads calculated as $57.14 \mathrm{ppm}$. pH values of irrigation water were determined as 7.6. TDS were determined as 256.70 ppm. If hardness is between 150 and 300 , it causes medium sized emitter clogging (James, 1988; Hills et al., 1989; Kuslu et al., 2005). On the other hand, the amounts of TDS less than $550 \mathrm{ppm}$, causes a small sized clogging, while higher values causes medium sized plugging (Pitts et al., 1990). So, water source used had no hardness value.

Table 2 indicates that current irrigation water source belong to $\mathrm{C}_{2} \mathrm{~S}_{1}$ class. US Salinity Laboratory Staff (USSL) (1954) method were used to determine class type. This method considered two factors such as EC and SAR. As a result, current irrigation water was determined as $2^{\text {nd }}$ class and had no negative effect on soil and plants. Since $\mathrm{Cl}$ value is less than 0.5 and TDS value between 175-525 ppm, irrigation water had no negative effect on soil and plants. It can be used safely (Table 3) (Çolakoğlu, 2010).

\section{Determination of Langelier saturation index value}

As a result of analysis, the optimum LSI value was determined as 2.48 . The first value created highly scale was selected. This mixture was made up to 1000 milliliters with water, $0.30 \mathrm{~g}$ of lime and $0.2 \mathrm{~g}$ of sodium hydroxid $(\mathrm{NaOH})$. The $\mathrm{NaOH}$ in this mixture were added to increase dissolution amount of lime (Table 4).

\section{Distribution of water into the system}

In order to achieve the desired percentages of clogging, in total, 12 tests were performed. As soon as the desired percentages of clogging were reached, the existing lateral was closed, but injection of the mixture into the other laterals continued.

The process was terminated when the desired cloggings were ensured for all laterals. In total, $9 \mathrm{HCl}$ acid applications were performed in different dates. These applications were continued approximately for 39 days. During each application, the concentration of $2.5,5,10$, 500 and $1000 \mathrm{ppm}$ acid were diluted with 1 ton of 
Table 4. Determination of appropriate LSI value.

\begin{tabular}{|c|c|c|c|c|c|c|c|c|c|c|c|c|c|}
\hline \multirow{2}{*}{ No } & \multirow{2}{*}{$\begin{array}{c}\text { Water } \\
\text { (mlt) }\end{array}$} & \multirow{2}{*}{$\begin{array}{l}\text { Lime } \\
(\mathrm{g})\end{array}$} & \multirow{2}{*}{$\begin{array}{c}\mathrm{NaOH} \\
(\mathrm{g})\end{array}$} & \multirow[b]{2}{*}{ pH } & \multirow{2}{*}{$\begin{array}{c}E C \\
(\mathrm{dS} / \mathrm{m})\end{array}$} & \multicolumn{2}{|c|}{$\begin{array}{ll}T \\
\end{array}$} & \multicolumn{2}{|c|}{$\mathrm{Ca}$} & \multicolumn{2}{|c|}{$\mathrm{Na}$} & \multirow[b]{2}{*}{ LSI } & \multirow{2}{*}{ LSI criteria } \\
\hline & & & & & & $\left({ }^{\circ} \mathrm{C}\right)$ & TF & (ppm) & CF & (ppm) & AF & & \\
\hline 1 & - & - & - & 7.60 & 0.41 & 26.5 & 0.650 & 16.6 & 0.706 & 3.5 & 0.490 & -2.65 & Highly corrosive \\
\hline 2 & 500 & 10.00 & 1.00 & 11.69 & 12.86 & 28.3 & 0.686 & 104 & 1.616 & 42 & 1.604 & 3.50 & Highly \\
\hline 3 & 500 & 7.50 & 1.00 & 11.98 & 13.55 & 27.1 & 0.662 & 211 & 1.922 & 177 & 2.254 & 4.72 & Highly \\
\hline 4 & 500 & 5.00 & 1.00 & 11.89 & 12.70 & 27.4 & 0.668 & 239 & 1.978 & 172 & 2.244 & 4.68 & Highly scale \\
\hline 5 & 1000 & 2.00 & 0.70 & 11.89 & 8.63 & 26.9 & 0.658 & 305.8 & 2.106 & 502 & 2.677 & 5.23 & Highly scale \\
\hline 6 & 1000 & 0.50 & 0.58 & 11.53 & 3.84 & 28.1 & 0.682 & 49 & 1.288 & 435 & 2.626 & 4.03 & Highly scale \\
\hline 7 & 1000 & 0.30 & 0.20 & 11.00 & 1,03 & 27.3 & 0.666 & 15.2 & 0.657 & 178.6 & 2.257 & 2.48 & Highly scale \\
\hline
\end{tabular}

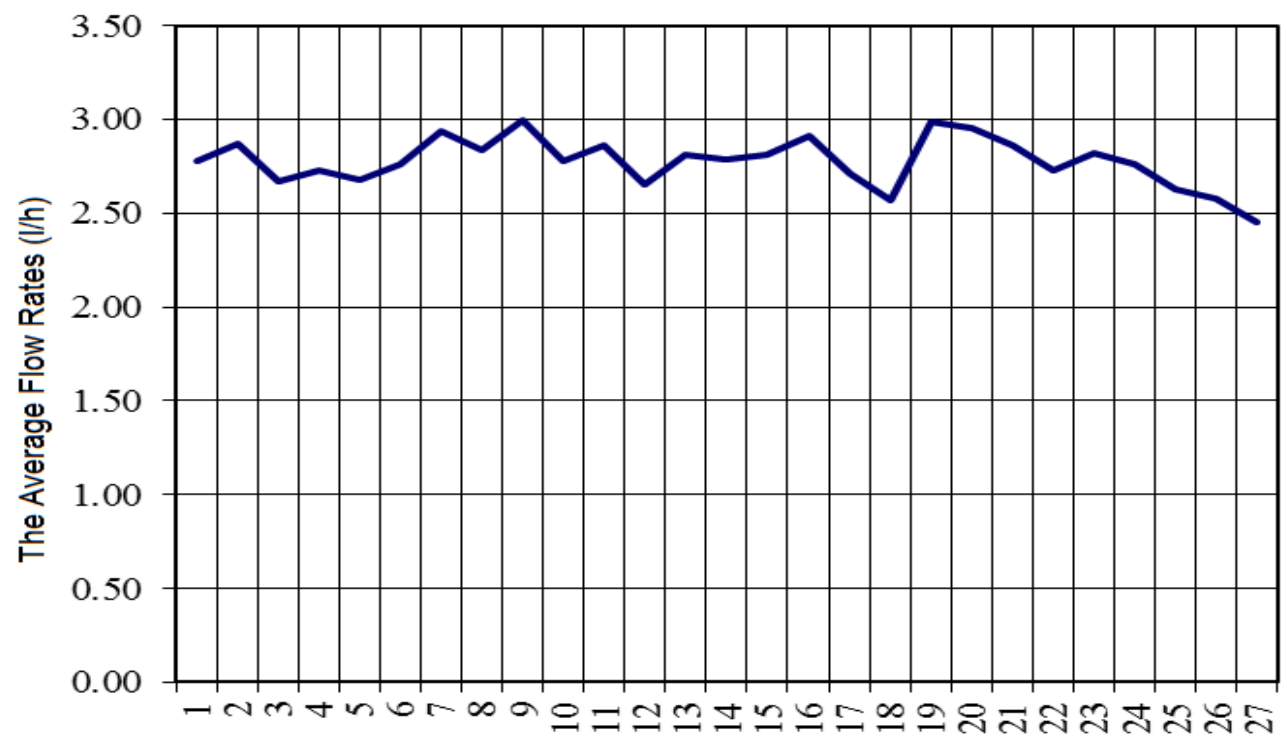

Lateral No

Figure 4. The average flow rate changes for 27 lateral lines.

irrigation water.

\section{Statistical analysis}

Analysis of variance of data showed that there was a significant difference between acid applications. But differences between the percentages of clogging were found not significant (Table 5). In the study, it was determined that the percentage of opening depended on the percentage of clogging and the application amounts of acid shown in Table 6. In the other acid applications excluding $1000 \mathrm{ppm}$, the percentages of opening increased with increased percentage of clogging. The lowest opening was at laterals of $2.5 \mathrm{ppm}$ with $3.25 \%$ and the highest opening was at lateral of $1000 \mathrm{ppm}$ with $40.91 \%$. At the concentrations of 500 and 1000 ppm, higher percentages of opening were not reached. The reason of this could be that the calcium carbonate reacted with $\mathrm{HCl}$ acid and the $\mathrm{Cl}$ remained free. Then, free $\mathrm{Cl}$ ions were precipitated by forming composite with ions such as $\mathrm{Ca}, \mathrm{Mg}$, $\mathrm{Na}$ in irrigation water.

\section{Effect of acid on clogging and system}

According to water quality classification, water analysis results were classified as excellent, in terms of $\mathrm{Cl}$ values. They had no effect. However, the concentration of 500 and $1000 \mathrm{ppm}$ was classified as severe (Ayers and Westcot, 1989). In terms of toxic effect in the soil, the concetrations of 500 (55.86) ppm and 1000 (94.25) ppm tended to be slightly harmful, but the concentation of 2.5, 5 and $10 \mathrm{ppm}$ were found to be harmless (Table 7). In the study, it was determined that flow rates along lateral lines differ by percentages of clogging. An average value was determined by using 27 lateral lines (Figure 4). The number one represented the nearest lateral to the pump, 
Table 5. Result of variance analysis.

\begin{tabular}{lccccc}
\hline Parameter & $\begin{array}{c}\text { Error sum of } \\
\text { squares }\end{array}$ & $\begin{array}{c}\text { Degree of } \\
\text { freedom }\end{array}$ & $\begin{array}{c}\text { Mean square } \\
\text { errors }\end{array}$ & F & P \\
\hline Application amounts of acid $\left(\mathrm{V}_{1}\right)$ & 83.780 & 2 & 41.890 & 7.365 & $0.004^{* *}$ \\
Percentage of clogging $\left(\mathrm{V}_{2}\right)$ & 21.811 & 2 & 10.906 & 1.917 & $0.171^{\text {ns }}$ \\
Error & 125.125 & 22 & 5.688 & & \\
General & 1244.068 & 27 & & & \\
\hline
\end{tabular}

${ }^{* *}$, Significant at $p<0.01 ; n s$, not significant.
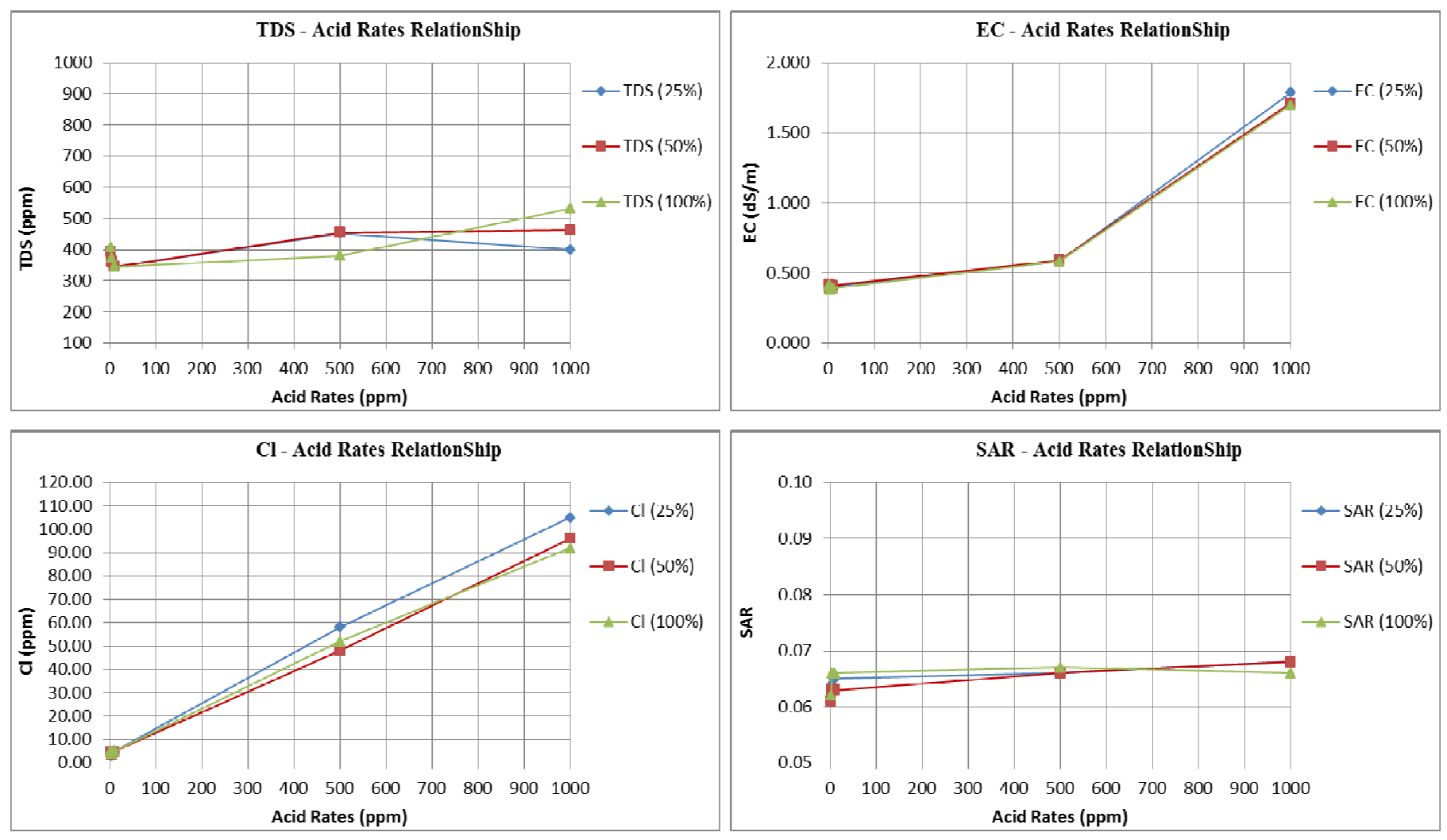

Figure 5. Changes in TDS, EC, CI and SAR with different acid rates.

the number twenty-seven represented the furthest lateral to the pump. The furthest lateral had the most clogged emitters, in other words, the lowest flow rates.

$\mathrm{pH}, \mathrm{EC}, \mathrm{SAR}$ and TDS changes were determined that depended on amounts of acid. As acid rates increased, $\mathrm{EC}$ and $\mathrm{Cl}$ increased. But TDS and SAR had no changes (Figure 5). As specified in Evans (2001), Cl should be between $\mathrm{pH}$ 5.5-6.0 for optimum effectiveness. In this study, $\mathrm{pH}$ values (for all application) ranged from 7.0-8.0. This situation prevented the elimination of clogging. Besides, 500 and 1000 ppm had lower pH values. This meant that more clogged emitters were opened. But, this high amount of acid also led to deterioration of quality parameters of irrigation water and showed a negative effect. These results indicated that 500 and 1000 ppm were economically not a good choice.

\section{Conclusion}

In general, it was seen that acid rates $(2.5,5$ and 10 ppm) had no enough effect on clogged emitters. Besides, acid rates with 500 and 1000 ppm had almost enough percentages of opening (15.38\% and $40.91 \%)$. The highest percentages of opening were seen at application rate of $1000 \mathrm{ppm}$ with $40.91 \%$, and the lowest were seen at application of $2.5 \mathrm{ppm}$ with $3.25 \%$. Nevertheless, the percentages of clogging used in this study were greater 
Table 6. Changes between percentages of opening depends on percentages of clogging and application amounts of acid.

\begin{tabular}{|c|c|c|c|c|}
\hline \multirow{3}{*}{$\begin{array}{l}\text { Application amounts of } \\
\text { acid (ppm) }\end{array}$} & \multicolumn{3}{|c|}{ Percentages of clogging (\%) } & \multirow{3}{*}{$\begin{array}{l}\text { Mean percentage of } \\
\text { opening (\%) }\end{array}$} \\
\hline & 25 & 50 & 100 & \\
\hline & \multicolumn{3}{|c|}{ Percentage of opening (\%) } & \\
\hline 2.5 & $3.25^{\mathrm{C}}$ & $3.80^{c}$ & $5.15^{b c}$ & $4.07 d$ \\
\hline 5 & $4.76^{b c}$ & $6.99^{c}$ & $7.59^{b c}$ & $6.45^{\mathrm{c}} \mathrm{d}$ \\
\hline 10 & $8.20^{b}$ & $8.53^{\mathrm{b}}$ & $8.38^{\mathrm{b}}$ & $8.37^{\mathrm{bc}}$ \\
\hline 500 & $5.56^{\mathrm{bc}}$ & $9.09^{b}$ & $15.38^{b}$ & $10.01^{b}$ \\
\hline 1000 & $40.91^{a}$ & $38.46^{\mathrm{a}}$ & $28.95^{\mathrm{a}}$ & $36.11^{\mathrm{a}}$ \\
\hline
\end{tabular}

$\mathrm{a}, \mathrm{ab}, \mathrm{b}, \mathrm{bc}, \mathrm{c}, \mathrm{cd}, \mathrm{d}$ : Duncan groups of irrigation methods $(\mathrm{P}>0.05)$.

Table 7. Chlorine toxic effect on soils (Çolakoğlu, 2010).

\begin{tabular}{ccl}
\hline $\mathbf{C l}(\mathbf{m e} / \mathbf{l})$ & $\mathbf{C l}(\mathbf{p p m})$ & Effect class \\
\hline$<2$ & $<70$ & None \\
$2-4$ & $70-140$ & Slightly harmful \\
$4-10$ & $140-350$ & Middle harmful \\
$>10$ & $>350$ & Severe \\
\hline
\end{tabular}

than those percentages of opening. This indicated that acid solutions with 500 and $1000 \mathrm{ppm}$ did not reached the desired percentages of opening compared with $2.5,5$ and $10 \mathrm{ppm}$ acid solutions. These results revealed that 500 and 1000 ppm is economically not desired. Consequently;

1. Percentages of clogging should not be more than $9 \%$ and acid applications should be at least $10 \mathrm{ppm}$ for elimination of this clogging in the system.

2. At first glance, although the increase in the amount of acid is seen as a good method, it can create harmful effect on plant, soil and system with time.

3. Plants that are very sensitive to $\mathrm{Cl}$ must not be grown, especially in high acid rate.

4. If irrigation water has low quality and high lime, a filter system must be used before acid injection.

\section{ACKNOWLEDGEMENT}

This study was supported by Academic Research Projects of Kahramanmaras Sutcu Imam University.

\section{ABBREVIATIONS}

SAR, Sodium adsorption rate; LSI, Langelier saturation index; EC, electrical conductivity; TDS, total dissolved solids; SAR, sodium adsorption ratio.

\section{REFERENCES}

Ayers RS, Westcot DW (1989). Water Quality for Agriculture. FAO Irrigation and Drainage, Rome. p. 29
Boman B, Ontermaa E (1994). Citrus Microsprinkler Clogging: Costs,

Causes, and Cures. University of Florida, IFAS Ft. Pierce Agricultural Research and Education Center 2199 South Rock Road Fort Pierce, FL 34945-3138 2A. Duda \& Sons, Inc. P. O. Box 788 LaBelle, FL 33935.

Bucks DA, Nakayama FS (1982). Principles and Potentialities of Trickle (Drip) Irrigation. Adv. Irrigation 1: 219-298.

Coelho RD (2001). Biological Clogging of Netafim's Drippers and Recovering Process Through Chlorination Impact Treatment. ASAE Annual International Meeting, 012231, California, USA.

Çolakoğlu H (2010). Sera Yetiştiriciliğinde Gübreleme. Toros Agricultural Industry, Trading Joint Stock Company. Agricultural Adviser. (http://www.toros.com.tr/dosyalar/ciftcidostu/gruplar/1_18801401_tarim_serayetistiriciligi.pdf)

Dehghanisanij H, Anioji H, Riahi H, Abou Elhassan, W (2007). Effect of Emitter Characteristics and Irrigation Schemes on Emitter Clogging Under Saline Water Use. J. Arid Land Stud. 16(4):225-233.

Evans RG (2001). Microirrigation, Irrigated Agriculture and Extension Center, Department of Biological Systems Engineering, Washington State University, Prosser, WA.

Gilbert RG, Nakayama FS, Bucks DA (1979). Trickle Irrigation: Prevention of Clogging. Trans. ASAE. 22(3):514-519.

Granberry DM, Harrison, KA, Kelley WT (2009). Drip Chemigation: Injecting Fertilizer, Acid and Chlorine. University of Georgia.

Güngör Y, Erözel AZ, Yildirim O (2004). Sulama. Ankara Üniversitesi Ziraat Fakültesi Yayınları, 1540/493, Ankara.

Hills DJ, Navar FM, Waller PM (1989). Effects of Chemical Clogging on Drip-Tape Irrigation Uniformity. Trans. ASAE 32(4):1202-1206.

James LG (1988). Principles of Farm Irrigation System Design. John Willey and Sons Inc., New York. p. 543.

Keller J, Bliesner RD (1990). Sprinkle and Trickle Irrigation. New York: Van Nostrand Reinhold.

Kuslu Y, Sahin U, Anapali O, Kiziloglu FM (2005). Damla Sulama Sistemlerinde Tikanma ve Giderilmesi ile Farkli Damlatici Tiplerinin Özellikleri. GAP IV. Tarim Kongresi Bildiri Kitabı, 2.Cilt, 1094-1101. 21-23 Eylul, Sanliurfa.

Netafim Irrigation, Inc. (2000). Chlorination of Drip Irrigation Systems. www.netafim.com, Fresno, CA.

Pitts DJ, Haman DZ, Smajstrla AG (1990). Causes and Prevention of Emitter Plugging in Microirrigation Systems. Bulletin 258, Fla. Coop. Ext. Serv., IFAS, Univ. of Florida (EDIS document no. AE032).

Rible JM, Meyer JL (1986). Cleaning Drip Irrigation Systems. p. 189191. in: D. F. Zoldoske MY. Miyaski (eds.). Micro-Irrigation Methods and Materials Update. Center for Irrigation Technology, Fresno, CA.

Smajstrla AG, Koo RC, Weldon JH, Harrison DS, Zazueta FS (1983). Clogging of Trickle Irrigation Emitters Under Field Conditions. Proc. Fla. State Hort. Soc. 96:13-17.

Stephen DE (1985). Filtration and Water Treatment for Microirrigation. Drip/Trickle Irrigation in Action, The Third International Drip /Trickle Irrig. Cong., ASAE publ, p.(1).

Tüzüner A (1990). Toprak ve Su Analiz Labaratuvarları El Kitabı. T.C. Tarım Orman ve Köyişleri Bakanlığı Köy Hiz. Genel Müd., Ankara, p.375s.

USSL (1954). Diagnosis and Improvement of Saline Alkali Soils. USDA Agr. Handbook N600. , Washington, D.C. 